\title{
Akt-dependent regulation of NF-кB is controlled by mTOR and Raptor in association with IKK
}

\author{
Han C. Dan, ${ }^{1}$ Matthew J. Cooper, ${ }^{1,2}$ Patricia C. Cogswell, ${ }^{1}$ Joseph A. Duncan, ${ }^{1}$ Jenny P.-Y. Ting, ${ }^{1}$ \\ and Albert S. Baldwin ${ }^{1,2,3,4}$ \\ ${ }^{1}$ Lineberger Comprehensive Cancer Center, University of North Carolina School of Medicine, Chapel Hill, North Carolina \\ 27599, USA; ${ }^{2}$ Curriculum in Genetics and Molecular Biology, University of North Carolina School of Medicine, Chapel \\ Hill, North Carolina 27599, USA; ${ }^{3}$ Department of Biology, University of North Carolina School of Medicine, \\ Chapel Hill, North Carolina 27599, USA
}

While NF-кB is considered to play key roles in the development and progression of many cancers, the mechanisms whereby this transcription factor is activated in cancer are poorly understood. A key oncoprotein in a variety of cancers is the serine-threonine kinase Akt, which can be activated by mutations in PI3K, by loss of expression/activity of PTEN, or through signaling induced by growth factors and their receptors. A key effector of Akt-induced signaling is the regulatory protein mTOR (mammalian target of rapamycin). We show here that mTOR downstream from Akt controls NF- $\mathrm{mB}$ activity in PTEN-null/inactive prostate cancer cells via interaction with and stimulation of IKK. The mTOR-associated protein Raptor is required for the ability of Akt to induce NF-kB activity. Correspondingly, the mTOR inhibitor rapamycin is shown to suppress IKK activity in PTEN-deficient prostate cancer cells through a mechanism that may involve dissociation of Raptor from mTOR. The results provide insight into the effects of Akt/mTOR-dependent signaling on gene expression and into the therapeutic action of rapamycin.

[Keywords: Akt; IKK; NF-кB; Raptor; mTOR]

Supplemental material is available at http://www.genesdev.org.

Received February 11, 2008; revised version accepted April 4, 2008.

The transcription factor NF- $\mathrm{B}$ is broadly associated with oncogenesis through its ability to control cell proliferation and to suppress apoptosis. Additionally, the NF-кB pathway in cancer has been associated with control of metastasis and angiogenesis (Basseres and Baldwin 2006; Karin 2006). The NF-кB family is comprised of five closely related members: p65/RelA, c-Rel, RelB, NF$\kappa \mathrm{B} 1 / \mathrm{p} 50$, and NF-кB2/p52 (Hayden and Ghosh 2004). NF$\kappa \mathrm{B}$ is activated downstream from signaling induced by inflammatory cytokines such as TNF or IL-1, bacterial endotoxin, and other innate immune response effectors, and during T-cell activation. Control of NF- $\kappa \mathrm{B}$ is most often regulated by the IKK complex through the phosphorylation of IкB proteins with subsequent ubiquitination and degradation, promoting nuclear accumulation of NF-кB dimers (Hayden and Ghosh 2004). IKK is comprised of two catalytic subunits, IKK $\alpha$ and IKK $\beta$, and a regulatory subunit, IKK $\gamma /$ NEMO (Israel 2000; Bonizzi and Karin 2004; Hayden and Ghosh 2004). Additionally, phosphorylation of the RelA/p65 subunit is associated

${ }^{4}$ Corresponding author.

E-MAIL abaldwin@med.unc.edu; FAX (919) 966-0444.

Article is online at http://www.genesdev.org/cgi/doi/10.1101/gad.1662308. with transcriptional activity of this NF- $\mathrm{B}$ subunit (Hayden and Ghosh 2004).

NF- $\mathrm{B}$ has been reported to be activated by oncoproteins and by loss of tumor suppressors, but the mechanisms associated with this activation are poorly understood at present (Basseres and Baldwin 2006). For example, it has been reported that the ser/thr kinase Akt can promote NF-кB activity. One group reported that Akt functions downstream from TNF to directly phosphorylate IKK $\alpha$ to activate NF-кB (Ozes et al. 1999), although this result was challenged (Delhase et al. 2000). We and others reported (Madrid et al. 2001; Sizemore et al. 2002) that Akt functions through IKK to promote the transactivation potential and phosphorylation (RelA) of NF-кB. Akt is proposed to promote metastasis and angiogenesis through IKK in a manner that depends on NF$\kappa \mathrm{B}$ and $\beta$-catenin activation (Agarwal et al. 2005).

Akt is an important regulator of cell growth and apoptosis that is activated downstream from PI3K and is inhibited by action of the tumor suppressor PTEN (Downward 1998; Cantley and Neel 1999; Hay 2005). Akt functions through its ability to phosphorylate a number of key pro-oncogenic targets that promote cell growth or inhibit apoptotic pathways (Hay 2005; Man- 
ning and Cantley 2007). For example, Akt phosphorylates and inactivates Foxo proteins that are proapoptotic through their ability to regulate the expression of genes that encode proteins that promote cell death (Tran et al. 2003; see Hay 2005). Additionally, a primary effector of Akt action is mTOR (mammalian target of rapamycin), itself a ser/thr kinase that phosphorylates S6K and 4EBP1 to regulate translation (Fingar and Blenis 2004; Hay and Sonenberg 2004). mTOR is associated with two complexes (Bhaskar and Hay 2007): the rapamycin-sensitive TORC1 complex that controls S6K phosphorylation, and TORC2 (Hay and Sonenberg 2004), which is the PDK2 activity that controls ser473 phosphorylation of Akt (Sarbassov et al. 2005). TORC1 is comprised of mTOR, Raptor, and G $\beta L$ (Hara et al. 2002; Kim et al. 2002, 2003), while TORC2 is comprised of mTOR, Rictor, and G $\beta \mathrm{L}$ (Sarbassov et al. 2005). The activation of TORC1 by Akt involves the phosphorylation of TSC2, which relieves a negative regulatory effect on mTOR controlled by the GTPase Rheb (Inoki et al. 2003; Manning and Cantley 2003). Additionally, it has been reported that Akt can regulate TORC1 through the control of cellular ATP levels and AMPK activity (Hahn-Windgassen et al. 2005). Recently, we showed that mTOR kinase activity in PTEN-null/inactive prostate cancer cells is regulated through an Akt-dependent interaction between IKK $\alpha$ and the mTOR-Raptor/TORC1 complex (Dan et al. 2007).

Both mTOR and PI3K/Akt are important in tumorigenesis through their ability to promote cell growth and responses to nutrients, and to suppress cell death (Vivanco and Sawyers 2002; Guertin and Sabatini 2005; Hay 2005; Majumder and Sellers 2005; Plas and Thompson 2005; Sabatini 2006; Shaw and Cantley 2006). Evidence for the involvement in mTOR and Akt in tumorigenesis has been provided with animal models using either constitutively active Akt in association with rapamycin treatment (Majumder et al. 2004) or deletion of PTEN in combination with Akt knockout (Chen et al. 2006). Additionally, Akt was shown to be highly dependent on TORC1 (see below) for transformation properties (Skeen et al. 2006). Although the anti-cancer and immunosuppressive drug rapamycin can function with FKBP12 to rapidly target the inhibition of TORC1 through the dissociation of raptor (see Sarbassov et al. 2006), its efficacy is not universal in cancer (Sawyers 2003), with tumors exhibiting expression defects in PTEN or VHL demonstrating sensitivity to the drug (Neshat et al. 2001; Podsypanina et al. 2001; Thomas et al. 2006).

Here we ask whether the Akt-dependent interaction between IKK and mTOR found in PTEN-deficient prostate cancer cells (Dan et al. 2007) controls NF-кB-dependent activity. The results show that the Akt-dependent mTOR and IKK interaction stimulates IKK activity directed toward the phosphorylation of I $\mathrm{B} \alpha$ and RelA/p65. Inhibition of expression of mTOR or Raptor blocks NF$\kappa \mathrm{B}$ activation and suppresses NF- $\kappa \mathrm{B}$-dependent gene expression. Additionally, rapamycin is shown to block NF$\mathrm{KB}$ activity in prostate cancer cells with no PTEN activity, consistent with its inhibitory effects on TORC1. These results provide new insight into the control of
NF- $\kappa \mathrm{B}$ activity downstream from Akt in certain cancer cells and a more complete understanding of the effects of rapamycin on certain cancer cells.

\section{Results}

Akt activity promotes an association between IKK $\alpha$ and mTOR in PTEN-null prostate cancer cells

We showed recently that elevated Akt activity in PC3 and LNCaP prostate cancer cells stimulates an association between IKK $\alpha$ and TORC1 to control the kinase activity of mTOR (Dan et al. 2007). As shown previously (Dan et al. 2007), siRNA-directed knockdown of Akt2 in PC3 cells leads to the dissociation of IKK $\alpha$ from the mTOR complex (Fig. 1A). Knockdown of Akt1 in PC3 cells, while quantitatively effective, does not significantly affect overall Akt activity in these cells and does not lead to the dissociation of IKK $\alpha$ from TORC1 (data not shown). Although IKK $\beta$ is found in the TORC1 complex in PC3 cells (Fig. 1B), knockdown of this IKK subunit only weakly affects mTOR activity (Dan et al. 2007), indicating a distinct role for IKK $\alpha$ in the regulation of mTOR downstream from Akt. Additionally, IKK $\gamma$ is also found in the mTOR complex, as shown by coimmunoprecipitation (Fig. 1B). The association of IKK $\beta$ and IKK $\gamma$ with the IKK $\alpha / \mathrm{mTOR}$ complex suggests the potential that NF-кB activation could occur through this interaction.

Size fractionation demonstrates that the IKK complex is associated with mTOR-Raptor in PC3 cells in a manner dependent on Akt

To extend the coimmunoprecipitation studies, PC3 cell extracts were analyzed by Superose 6 HPLC column chromatography (see the Materials and Methods). Column fractions 9 through 19 were analyzed by immu-
A

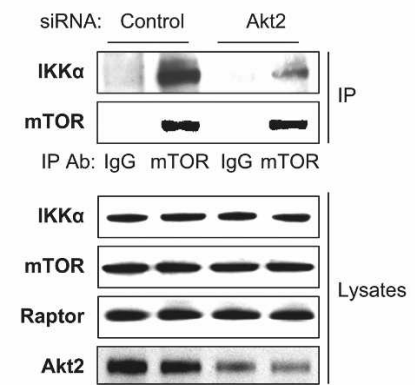

B

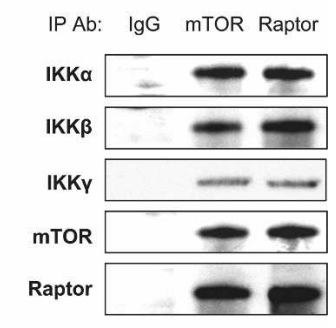

Figure 1. Akt promotes mTOR association with IKK $\alpha$. (A) PC3 cells were transfected with siRNA control or siRNA to Akt2 as indicated. The cells were lysed $48 \mathrm{~h}$ after transfection and the lysates were immunoprecipitated with anti-mTOR, electrophoresed on an SDS gel, and blotted with $\mathrm{mTOR}$ and IKK $\alpha$ antibodies, respectively (see Dan et al. 2007). Lysates were probed with these antibodies plus anti-Raptor and anti-Akt2. (B) The lysates were immunoprecipitated with anti-mTOR, anti-Raptor, and IgG control; electrophoresed on an SDS gel; and blotted with mTOR, Raptor, IKK $\alpha$, and IKK $\beta$, and IKK $\gamma$ antibodies. 
noblotting with antibodies for mTOR, Raptor, IKK $\alpha$, IKK $\beta$, and IKK $\gamma$ (Fig. 2A). mTOR and Raptor were found at highest levels in fractions 14-16, with lower levels in fractions 13 and 17. This pattern of size-dependent distribution of mTOR and Raptor is very similar to that reported by Guan and colleagues (Yang et al. 2006). IKK $\alpha$ and IKK $\beta$ were found at highest levels in fractions 13-15, with IKK $\gamma$ also found in fractions 13-15 (Fig. 2A). To determine whether IKK and MTOR associate in these column fractions, mTOR was immunoprecipitated from fractions 9-19 and the immunoprecipitate was analyzed by immunoblotting for IKK proteins (Fig. 2A). The results show that mTOR is associated with IKK subunits at the highest levels in fraction 14, with detectable association in fractions 13 and 15. Reciprocally, immunoprecipitation with IKK $\alpha$ antibody in fractions 13-15 shows that IKK is associated with $\mathrm{mTOR} / \mathrm{Raptor}$ in fractions 14 and 15 and only weakly in fraction 13 (data not shown). In that immunoprecipitation experiment, there is little Raptor associating with the IKK complex in fraction 13. These results suggest that a large portion of IKK is associated with mTOR in fractions 14 and 15, with less association in fraction 13. To determine whether Akt is required for the association between IKK and mTOR, as measured through column fractionation and immunoblotting, Akt2 was knocked down in PC3 cells. As shown earlier, siRNA treatment was effective at suppressing expression of Akt2, as compared with control siRNA (Fig. 2B). Column fractionation of extracts from siRNA control-treated and Akt siRNA treatment was performed as described earlier and fractions were analyzed by immunoblotting for mTOR, Raptor, and the IKK $\alpha$ and IKK $\beta$ subunits. With the siRNA control treat- ment of PC3 cells, fractionation followed by immunoblotting (Fig. 2B) was similar to that shown in Figure 2A. In the Akt2 siRNA experiment, immunoblotting for IKK $\alpha$ and IKK $\beta$ demonstrates that fractions 14 and 15 have lost IKK $\alpha$ and IKK $\beta$ following knockdown of Akt2 (Fig. 2B). Under these Akt2-deficient conditions, IKK $\alpha$ and IKK $\beta$ are largely localized in fraction 13. While it is possible that IKK found in fractions 14 and 15 have associated with other proteins to shift to fraction 13 , we favor the concept that most of the IKK in fraction 13 was not affected by Akt knockdown. This is based on results showing that immunoprecipitation of IKK in fraction 13 only weakly pulls down mTOR with very little Raptor (data not shown). That some mTOR remains in fractions 14 and 15 under the Akt siRNA knockdown conditions suggests that either the loss of IKK subunits from the mTOR complex leads to association with different proteins to maintain a roughly similar mass or that only a portion of the mTOR in those fractions was associated with IKK, and that the portion of $\mathrm{mTOR}$ associated with IKK was either destabilized or shifted to other fractions. Consistent with the latter hypothesis, the mTOR-associated protein Rictor is detected in fractions 14 and 15 (also seen in equivalent fractions in Yang et al. 2006) and the mTOR-Rictor protein complex is presumably insensitive to Akt knockdown. Overall, these results support the coimmunoprecipitation experiments shown in Figures $1 \mathrm{~B}$ and $2 \mathrm{~A}$, indicating that $\mathrm{mTOR}$ and IKK form an Akt-dependent complex in PC3 cells.

mTOR regulates $N F-\kappa B$ in a manner dependent on Akt Based on the Akt-dependent interaction between mTOR/ Raptor and IKK subunits, we hypothesized that Akt
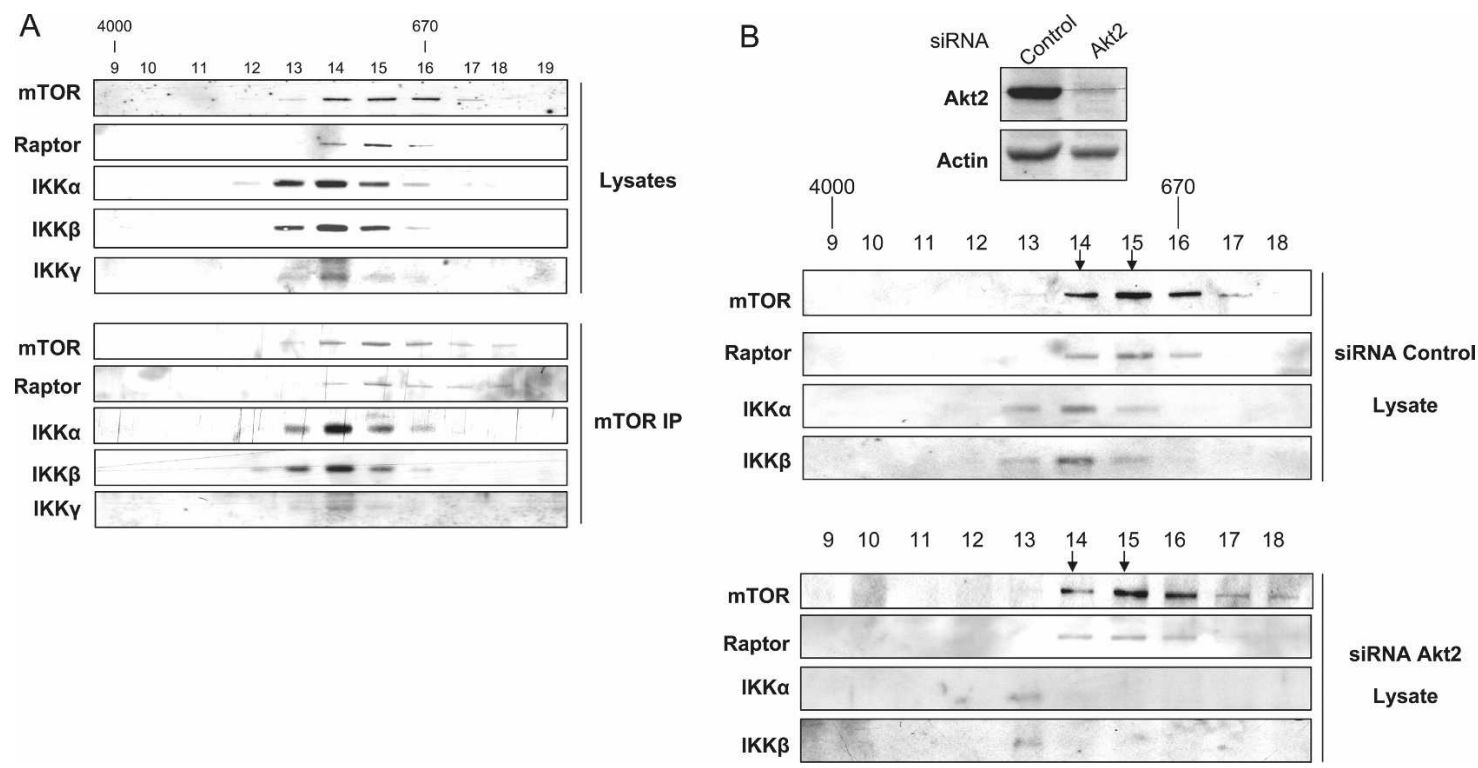

Figure 2. Size fractionation demonstrates that the IKK complex is associated with mTOR-Raptor. $(A)$ PC3 cell lysates were separated on a Superose 6 10/300 GL column. The indicated fractionations (top panel) and their mTOR immunoprecipitates (bottom panel) were analyzed by immunoblotting with the indicated antibodies. (B, top panel) PC3 cell were transfected with control siRNA and siRNA akt2, and Western blot shows the mTOR and Raptor expression. (Bottom panel) Lysates were separated on a Superose 6 10/300 GL column and the indicated fractions were analyzed by immunoblotting with the indicated antibodies. 
regulation of NF-кB activation is dependent on the interaction between mTOR and IKK. Support for this hypothesis would provide a molecular mechanism to explain how Akt could activate NF- $\mathrm{B}$ in a manner dependent on IKK (Madrid et al. 2001; Sizemore et al. 2002). To address whether mTOR can stimulate NF-кB activity, PC3 and LNCaP prostate cancer cells, as well as HeLa cells, were transfected with an NF-кB-dependent reporter and with an empty vector or an expression vector for mTOR. Cell extracts were prepared and luciferase activity was quantified for the different transfection conditions. The results of the experiments demonstrate that PC3 and LNCaP cells exhibit higher NF-kB-dependent reporter activity as compared with HeLa cells (Fig. 3A). Expression of mTOR in all three cell types enhanced reporter activity, although HeLa cells exhibited the lowest level of stimulation. To determine whether endogenous NF-кB activity in PC3 cells is controlled by TORC1, siRNA to mTOR or to Raptor was utilized in parallel with a control siRNA. Knockdown of mTOR or of Raptor strongly blocked NF-кB-dependent reporter activity in PC3 cells, but was less effective in suppressing HeLa cell-associated NF-кB activity (Fig. 3B, left panel). This latter result is consistent with the fact that HeLa cells exhibit relatively low endogenous Akt activity. As an important control, overexpression of mTOR under mTOR siRNA knockdown conditions led to a partial restoration of NF-кB-dependent luciferase activity (data not shown). Additionally, knockdown of IKK $\alpha$ or IKK $\beta$ suppressed NF-kB-dependent reporter activity in PC3 cells (Fig. 3B, right panel). To determine whether Akt is important for the observed NF- $\mathrm{B}$ activity in PC3 cells, siRNA to Akt2 was utilized. Knockdown of Akt2 reduced NF-кBreporter activity $\sim 70 \%$ in PC3 cells (Fig. 3C). Transfection of mTOR induced NF- $\mathrm{B}$ activity $\sim 3.5$-fold in PC3 cells, and this response is suppressed with knockdown of Akt2 (Fig. 3C). This result indicates that basal NF-кB activity in PC3 cells is controlled by Akt and that the ability of mTOR to activate NF- $\mathrm{B}$ in these cells is dependent, at least partly, on Akt. To pursue this issue further, PTEN was transfected into PC3 cells (PTEN-null) and NF-кB-reporter activity was measured. Expression of PTEN reduced basal NF-кB activity in PC3 cells $\sim 50 \%$, and similarly suppressed the ability of mTOR to induce NF-кB (Fig. 3D). Additionally, PC3 or LNCaP cells were transfected with the NF-кB-dependent luciferase reporter, and cells were left untreated or were exposed to either a PI3-kinase antagonist (LY294002) or to rapamycin, an inhibitor of mTOR activity. Subsequently, cell extracts were prepared and luciferase measured. Both LY294002 and rapamycin reduced NF$\kappa \mathrm{B}$-dependent reporter activity in PC3 and LNCaP cells (Fig. 3E). Additionally, the results indicate that PC3 cells appear to be more dependent on Akt and mTOR than LNCaP cells, relative to the effects of the inhibitors on NF-кB-dependent reporter activity (Fig. 3E). To show that the ability of mTOR to activate the NF- $\mathrm{BB}$-dependent reporter is IKK-dependent, PC3 were treated with siRNA control or siRNA to IKK $\alpha$ and luciferase activity measured. The data reveal that siRNA to IKK $\alpha$ blocks basal levels of NF-кB-dependent reporter activity and suppresses the ability of mTOR to induce the reporter (Fig. 3F). Overall, the results from this group of experiments support the hypothesis that Akt is important for NF-кB-dependent activity in prostate cells that are inactive for PTEN and that $\mathrm{mTOR}$ is a critical intermediate in this signaling pathway.

Expression of NF-кB-dependent genes in PC3 cells is controlled by $\mathrm{mTOR}$ and Raptor

In order to determine whether mTOR and Raptor contribute to the expression of genes known to be regulated by NF- $\mathrm{B}$, either mTOR or Raptor were knocked down with siRNA in PC3 cells. RNA was isolated from these cells and from cells exposed to control siRNA. Expression of Bcl-2, cIAP1, XIAP, IкB $\alpha$, and cyclinD1 were measured with RT-PCR. GAPDH gene expression served as a control for these experiments. Knockdown of mTOR blocked expression of the experimental gene set $\sim 30 \%-$ $40 \%$, while knockdown of Raptor reduced expression of these genes $\sim 50 \%$ (Fig. 4). GAPDH expression was unaffected by either siRNA treatment. These results, with the data presented in Figure 2, demonstrate that mTOR and Raptor signal to regulate endogenous NF-кB-dependent gene expression in PTEN-deficient prostate cancer cells in a manner dependent on Akt.

mTOR and Raptor control NF-кB DNA-binding activity and RelA/p65 phosphorylation in PC3 cells

To determine mechanisms of regulation of endogenous NF-кB by mTOR and Raptor, extracts (whole cell and nuclear) were prepared from PC3 cells treated with control siRNA or with siRNA for either mTOR or Raptor. Electrophoretic mobility shift assays (EMSAs) were performed with nuclear extracts using a class I MHC NFкB-binding site probe. As shown in Figure 5A, siRNA either to mTOR or to Raptor reduced NF- $\mathrm{B}$ DNA-binding activity, although knockdown of mTOR was more effective in blocking the EMSA complex (Fig. 5A). Analysis of SP1 binding in the extracts shows that there is equivalent loading for the different experimental conditions (Fig. 5A). The efficacy of knockdown of mTOR and Raptor in these experiments is shown in Figure 5D. Transfection of mTOR into PC3 cells led to an increase in NF-кB DNA-binding activity, as measured through EMSA (Fig. 5B), and rapamycin treatment of PC3 cells suppressed NF-кB DNA-binding activity (Fig. 5C). Phosphorylation of both IкB $\alpha$ and RelA/p65 correlate with IKK activity, and ultimately with NF-кB activity (Hayden and Ghosh 2004). Endogenous expression of either mTOR or Raptor in PC3 was knocked down with siRNA, and phosphorylation of RelA/p65 at ser536 or Iк $\mathrm{B} \alpha$ at ser32/36 was measured with phospho-specific antibodies. Results from this experimentation showed that knockdown of mTOR or of Raptor each blocked phosphorylation of RelA/p65 and of IкB $\alpha$ (Fig. 5D). Additionally, knockdown of IKK $\alpha$, IKK $\beta$, or Akt2 in PC3 cells reduced p65 and $\mathrm{I}_{\kappa} \mathrm{B} \alpha$ phosphorylation (Fig. 5 E,F). Transfection of mTOR into PC3 cells induced RelA/p65 ser536 phosphorylation (Fig. 5F), and LY294002 and rapamycin individually suppressed RelA/p65 phosphorylation (Fig. 5G). In the latter experiment, LY and rapamycin 
Dan et al.
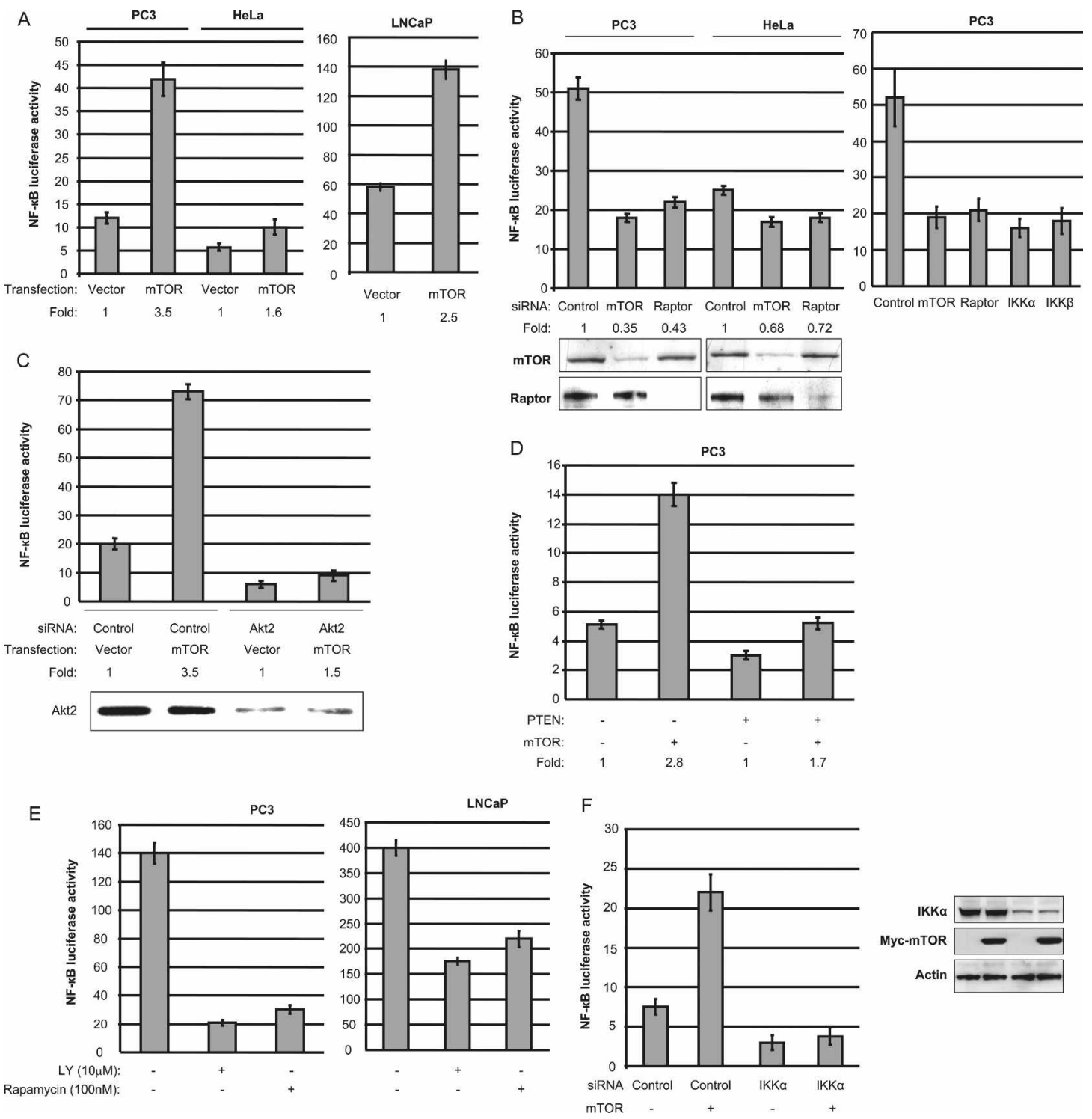

Figure 3. $\mathrm{mTOR} /$ Raptor positively regulates NF-кB-dependent luciferase reporter activity in PTEN-deficient prostate cancer cells in a manner dependent on Akt. (A) PC3, LNCaP, and HeLa cells were transfected with $700 \mathrm{ng}$ of mTOR expression vector or empty vector plus $200 \mathrm{ng}$ of $3 \times \kappa \mathrm{B}$ luciferase reporter and $30 \mathrm{ng}$ of pRL-SV40 (Renilla reporter control). Cells were harvested after $24 \mathrm{~h}$ and luciferase assays were performed (measured as relative luciferase/luminescence units). (B) PC3 and HeLa cells were transfected with the NF-кB-dependent luciferase reporter and control siRNA, or siRNA to mTOR, Raptor, IKK $\alpha$, or IKK $\beta$, as indicated. Luciferase assays were performed as in $A$ after $24 \mathrm{~h}$. Levels of luciferase are compared with the siRNA control for each cell type. Western blot shows the mTOR and Raptor protein levels. (C) PC3 cells were transfected the NF-кB-dependent luciferase reporter and either empty vector or mTOR expression vector, and with control siRNA, or siRNA to Akt2, as indicated. Luciferase assays were performed as in $A$ after 48-h transfection of siRNA. (D) PC3 cells were cotransfected with mTOR and/or PTEN with $3 \times \kappa B$ luciferase reporter and 30 ng of pSV40-RL as indicated. Luciferase assays were performed as in $A$ after $24 \mathrm{~h}$ transfection. (E) PC3 and LNCaP cells were transfected as described above, and then treated with LY294002 (3 h) or Rapamycin (3 h) $24 \mathrm{~h}$ after transfection. Luciferase assays were performed as in $A$. SD is shown and is representative of at least three experiments. $(F)$ PC3 cells were transfected with control siRNA, or siRNA to IKK $\alpha$, as indicated. The NF-кB-dependent luciferase reporter and either empty vector or mTOR expression were transfected $24 \mathrm{~h}$ after siRNA transfection, and luciferase assays were performed as in $A$ after 48 -h transfection of siRNA. Immunoblotting for expressed proteins is shown. Experiments were performed in triplicate and SD is shown.

cin each blocked mTOR activity as detected through phosphorylation of S6K using the T389 phospho-specific antibody. These experiments show that phosphorylated Akt (S473) is increased following rapamycin treatment, consistent with the findings of others $\left(\mathrm{O}^{\prime}\right.$ Reilly et al.
2006; Shah and Hunter 2006), which show that S6K feeds back to block IRS-1 through phosphorylation. Inhibition of this response can lead to growth factorinduced PI3K and Akt activation. In summary, these experiments indicate that mTOR and Raptor, through an 


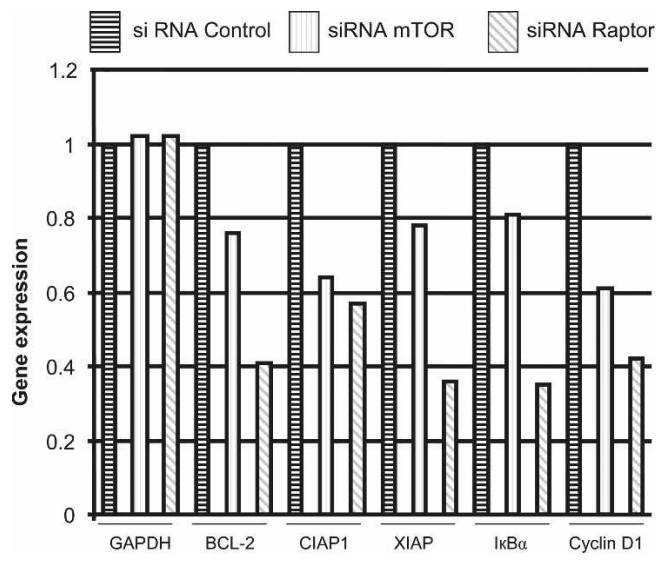

Figure 4. mTOR/Raptor is involved in control of NF- $к B$ target gene expression in PC3 cells. PC3 cells were transfected with control siRNA, or siRNA to mTOR or Raptor, as indicated. RNA was extracted $48 \mathrm{~h}$ after transfection and RT-PCR (see the Materials and Methods) was performed to assess changes in mRNA levels of NF- $\kappa \mathrm{B}$ target gene expression. A representative experiment from among three others is shown.

Akt-dependent pathway, control NF- $\mathrm{B}$ activity in PC3 prostate cancer cells both at the level of IкB $\alpha$ and RelA/ p65 phosphorylation.

\section{mTOR controls IKK activity downstream from Akt}

The regulation of IкB $\alpha$ and RelA/p65 phosphorylation by $\mathrm{mTOR}$ and Raptor suggests that these proteins may activate IKK. In order to address this hypothesis, several different experiments were performed. siRNA experiments in PC3 cells revealed that knockdown of either $\mathrm{mTOR}$ or Raptor reduced endogenous phosphorylation of IKK $\alpha$ and IKK $\beta$ in their activation loops (Fig. 6A). Using the same knockdown approach, immunoprecipitated IKK (via immunoprecipitation of IKK $\alpha$ ) demonstrated reduced IKK in vitro kinase activity using IкB $\alpha$ as a substrate (Fig. 6B). Immunoprecipitated IKK $\alpha$, IKK $\beta$, and IKK $\gamma$ demonstrated reduced in vitro phosphorylation of a C-terminal fragment of RelA/p65 when either mTOR or Raptor were knocked down with siRNA (Fig. 6C). Myctagged mTOR was transfected into PC3 cells and endogenous IKK $\alpha$, IKK $\beta$, or IKK $\gamma$ was immunoprecipitated and used in an in vitro kinase assay using recombinant IкB $\alpha$ as a substrate. Results from this experiment demonstrate that expression of mTOR stimulates IKK activity (Fig. 6D). Similarly, immunoprecipitated IKK subunits demonstrated enhanced in vitro activity against recombinant C-terminal RelA/p65 following mTOR expression (Fig. 6E). To further analyze mTOR-dependent IKK activity, column fractions 14-17 (see Fig. 2A) were immunoprecipitated with $\mathrm{mTOR}$, and an IKK assay was performed using recombinant $\mathrm{I} \kappa \mathrm{B} \alpha$ as a substrate (Fig. $6 \mathrm{~F}$ ). These fractions were chosen since fractions 14 and 15 exhibit mTOR-IKK association, while fraction 16 exhibits mTOR and Raptor but not significant levels of IKK subunits. Fraction 17 is relatively weak for all of these pro- teins. Immnunoprecipitation of mTOR reveals that fraction 14 has the highest IKK activity, while fraction 15 is reduced, consistent with lower levels of mTOR-associated IKK. Fraction 16, although it has mTOR and Raptor, has very low levels of associated IKK and correspondingly low IKK activity. Fraction 17 exhibits no IKK activity following mTOR immunoprecipitation. These results demonstrate that mTOR-associated IKK in PC3 cells exhibits activated kinase activity.

Rapamycin inhibits IKK activity, potentially through dissociation of Raptor from the mTOR complex

Rapamycin suppresses mTOR activity through interaction with FKBP12 and the subsequent interaction of the FKBP12/rapamycin complex with mTOR (see Sawyers 2003). Thus, we considered the possibility that rapamycin would inhibit IKK activity in PTEN-deficient cells. PC3 cells were left untreated or were treated with rapamycin for $2 \mathrm{~h}$. IKK $\alpha$ was immunoprecipitated and used in an in vitro kinase assay as described above. The results from this experiment indicate that rapamycin suppresses IKK activity (Fig. 7A), consistent with our findings regarding the ability of mTOR to regulate IKK in PC3 cells. Additionally, rapamycin blocked RelA/p65 phosphorylation that occurs constitutively in PC3 prostate cancer cells. Rapamycin was also shown to inhibit S6K phosphorylation, consistent with the effects of rapamycin on TORC1. Rapamycin has been shown to disrupt Raptor from mTOR in the TORC1 complex (Sarbassov et al. 2006). We asked whether rapamycin would disrupt IKK $\alpha$ from TORC1, potentially explaining the effects of rapamycin on PC3 cell-associated NF- $\kappa$ B activity. PC3 cells were untreated or were treated with rapamycin for $2 \mathrm{~h}$, and mTOR was immunoprecipitated. The immunoprecipitate was tested for the presence of Raptor, mTOR, and IKK $\alpha$ by immunoblotting. Results indicate that rapamycin dissociates Raptor from the mTOR/TORC1 complex, consistent with the results of Sarbassov et al. (2006), but does not dissociate IKK $\alpha$. These results, which are consistent with the siRNA knockdown experiments shown above, support the hypothesis that Raptor is required in association with mTOR to regulate IKK activity and downstream NF- $\kappa$ B activation in PC3 cells. We recognize that rapamycin could affect a distinct signaling step in the IKK pathway, although rapamycin does not significantly block TNF-induced NF- $\kappa$ B activation in several cell types or constitutive activation of NF- $\mathrm{KB}$ in cancer cells that exhibit low Akt activity (data not shown). The results also indicate that Raptor is not required for association of IKK $\alpha$ with the mTOR complex.

\section{Discussion}

NF- $\kappa$ B activation induced downstream from cytokines and other inflammatory and immune regulators involves the activation of IKK by upstream mediators such as RIP2 and Tak1, followed by phosphorylation and degradation of IкB in association with phosphorylation of 
Dan et al.

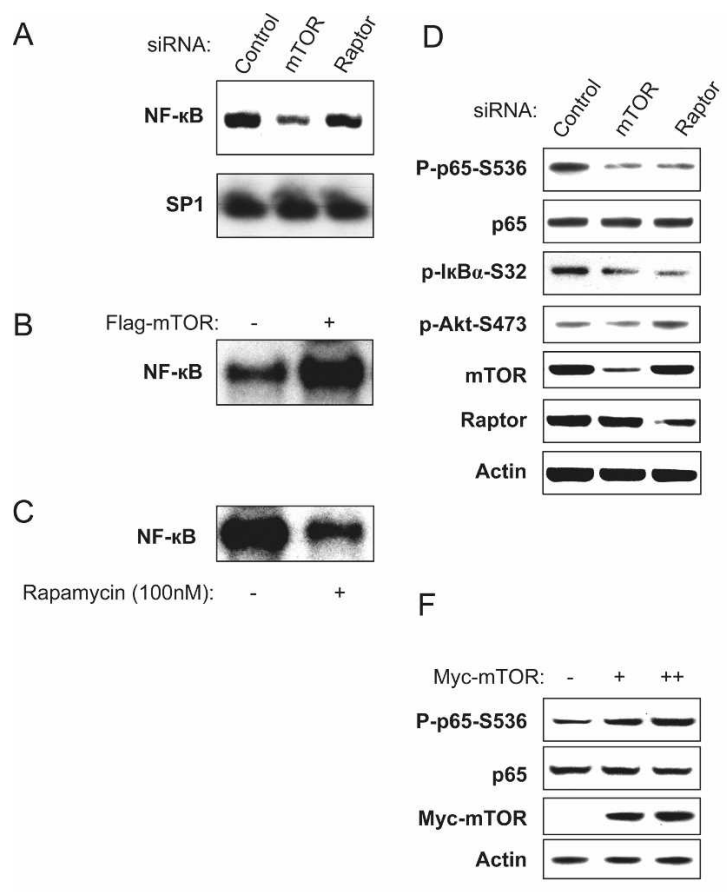

$\mathrm{E}$
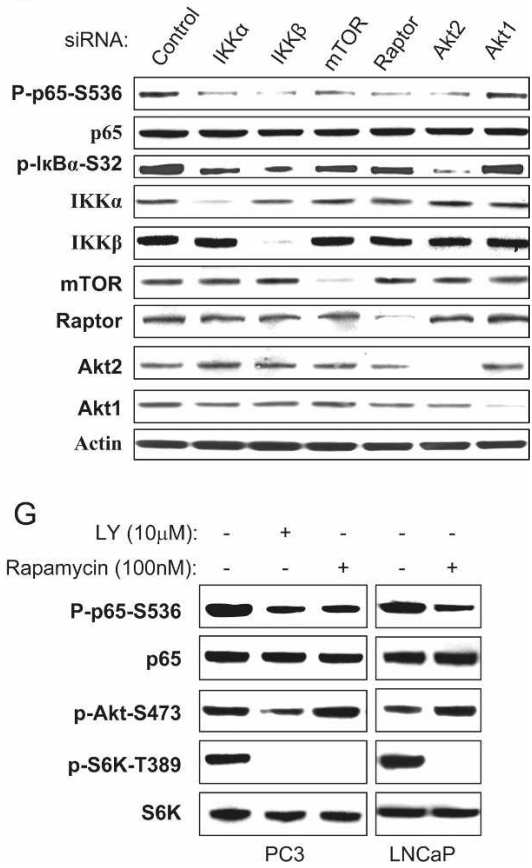

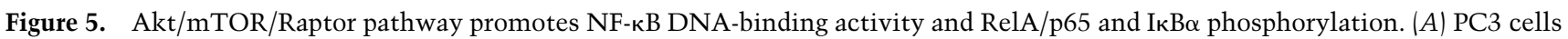
were transfected with control siRNA, or siRNAs to mTOR or Raptor, as indicated. EMSAs were performed using nuclear extracts from cells lysed $48 \mathrm{~h}$ after transfection. A radiolabeled SP1 probe was used to normalize protein loading. (B) PC3 cells were transfected with mTOR expression vector or empty vector (control). EMSAs were performed using nuclear extracts from cells $48 \mathrm{~h}$ after transfection. (C) PC3 cells were treated with Rapamycin (100 nM) or DMSO for $2 \mathrm{~h}$. Electrophoretic gel shift assays were performed using nuclear extracts from the cells as in $A$. $(D, E)$ PC3 cells were transfected with siRNA control or other siRNAs, as indicated (IKK $\alpha$, IKK $\beta$, mTOR, Raptor, Akt1, or Akt2). The cells were lysed $48 \mathrm{~h}$ after transfection and the levels of IKK $\alpha$, IKK $\beta, \mathrm{mTOR}, \mathrm{Raptor}, \mathrm{Akt1}$, Akt2, and $\beta$-tubulin, and of endogenous phosphorylation of P65, Akt, and IкB $\alpha$ were determined by immunoblotting with the indicated antibodies. (F) PC3 cells were transfected with myc-mTOR wild type or vector control as indicated. Cell lysates were generated and blotted with phospho-p65-S536, p65, S6K and myc tag, and actin antibodies, as indicated. (G) PC3 cells were treated with Rapamycin (100 nM) or DMSO for $2 \mathrm{~h}$. Cell lysates were generated and blotted with the antibodies as indicated. Experiments are representative of three replicates.

RelA/p65 (Bonizzi and Karin 2004; Hayden and Ghosh 2004). In these signaling pathways, NF-кB accumulates in the nucleus and binds to target sequences to control transcriptional responses. In cancer cells, NF-кB activation has been described to occur downstream from oncoproteins such Ras and BCR-ABL, but specific signaling mechanisms involved with the induction of this transcription factor are poorly characterized at present (Basseres and Baldwin 2006). Akt, a ser-thr kinase that exhibits elevated activity in a number of cancers (Hay 2005), has also been reported to activate NF-кB, but, again, this response is not well understood. Our group and that of George Stark reported that Akt utilizes IKK to activate NF- $\mathrm{\kappa B}$ transactivation potential and induce RelA/p65 phosphorylation (Madrid et al. 2001; Sizemore et al. 2002). Here we explore a mechanism to explain the origin of NF- $\mathrm{KB}$ activity downstream from constitutively activated Akt in PTEN-deficient prostate cancer cells.

Previously, we showed that IKK $\alpha$ is an important regulator of mTOR activity, associated with TORC1, in PTEN-deficient PC3 and LNCaP cells (Dan et al. 2007). Another group showed that IKK $\beta$ can induce mTOR, in an Akt-independent manner, through direct phosphory- lation of TSC1 (Lee et al. 2007). Our original studies indicated that constitutively active Akt induces an association between IKK $\alpha$ and the TORC1 complex in these cells and that IKK $\alpha$ induces mTOR kinase activity directed against S6K and 4E-BP1. It was found that IKK $\beta$ also associates with TORCl in an Akt-dependent manner (see Fig. 1B), but that knockdown of IKK $\beta$ expression only weakly affected mTOR kinase activity (Dan et al. 2007), indicating a largely unique role for IKK $\alpha$ in this process. Based on those observations, we hypothesized that the interaction between mTOR and IKK, while controlling mTOR kinase activity in PTEN-deficient prostate cancer cells, may reciprocally stimulate IKK activity to induce NF-кB. The experiments presented in this study strongly support this hypothesis. Using expression of mTOR and knockdown of endogenous mTOR and Raptor, we demonstrate that TORC1 regulates NF- $\mathrm{KB}$ at the level of DNA binding, RelA/p65 phosphorylation, and reporter and endogenous gene expression. Immunoprecipitation and in vitro kinase assays demonstrate that mTOR and Raptor induce IKK activity in an Akt-dependent manner. The results provide a molecular mechanism to explain how Akt regulates NF-kB activity, at 
A

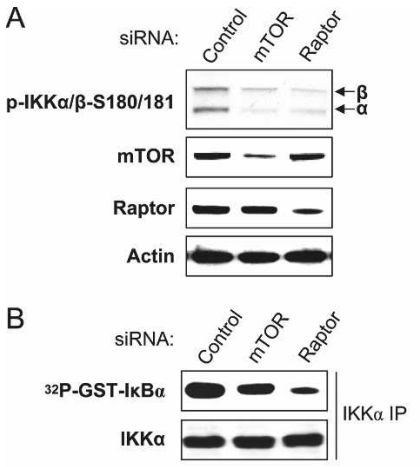

C

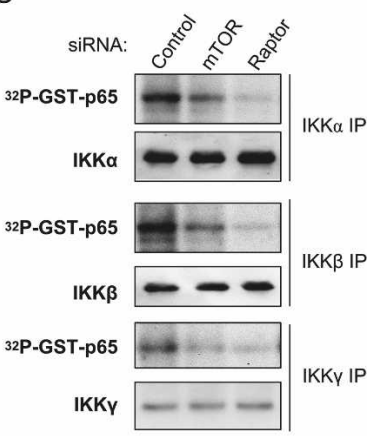

$\mathrm{D}$

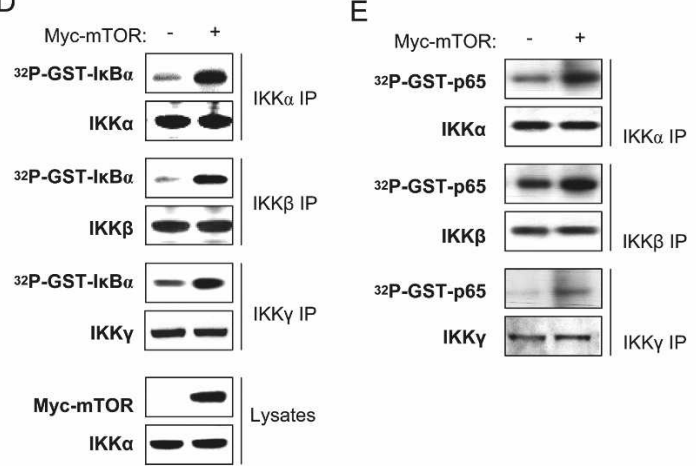

$\mathrm{F}$

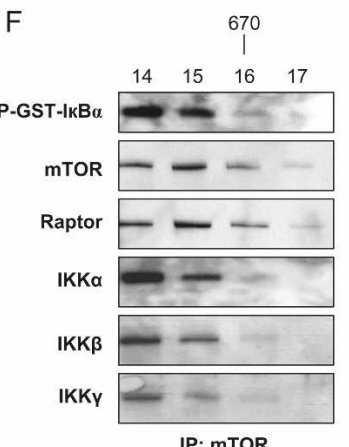

Figure 6. $\mathrm{mTOR} /$ Raptor pathway enhances IKK kinase activity in Akt-active cells. (A) Depletion of MTOR and Raptor with siRNA decreases phosphorylation of IKK $\alpha$ and IKK $\beta$ in their activation loops. $(B, C)$ Depletion of mTOR and Raptor with siRNA decreases IKK activity in PC3 cells, as measured by in vitro IKK kinase assay using GST-IкB $\alpha$ or GST-p65 as substrate. $(D, E)$ PC3 cells were transfected with myc-mTOR or vector control. Endogenous IKK $\alpha, \operatorname{IKK} \beta$, or IKK $\gamma$ were immunoprecipitated and IKK kinase activity directed toward GST-p65 was determined in the immunoprecipitates. $(F)$ PC3 cell lysates were separated on a Superose 6 10/300 GL column. Anti-mTOR precipitates from the indicated fractionations were incubated with GST-IкB $\alpha(1-54)$ and ${ }^{32} \mathrm{P}-\gamma$-ATP for kinase assay and were analyzed by immunoblotting with the indicated antibodies.

least in PTEN-deficient prostate cancer cells. The data also provide a mechanism to explain the ability of mTOR to promote cell survival, since NF-kB is known to regulate the expression of genes that suppress apoptosis.

What is the nature of the IKK-mTOR complex in PC3 cells? Using PC3 cell lysates, mTOR antibody

immunoprecipitates mTOR and Raptor, as expected, and each of the three IKK subunits. This complex (or complexes) is found at the highest levels in column fractions 14 and 15 , with a molecular mass of $>700 \mathrm{kD}$ (Fig. 2). The relative size of the IKK complex in PC3 cells is similar to what has been found in other fractionation studies (Chen et al. 2002). Additionally, the distribution of mTOR and Raptor in these fractions is very similar to that reported by Guan and colleagues (Yang et al. 2006). It is unclear at present whether this complex contains other regulatory molecules known to be associated with IKK (such as cdc37 and Hsp90) (see Chen et al. 2002) or with mTOR (such as G $\beta \mathrm{L}$ ). The stability of this complex requires Akt, as knockdown of Akt2 caused a disappearance of IKK $\alpha$ and IKK $\beta$ from column fractions 14 and 15, with IKK $\alpha$ in column fraction 13 largely unaffected. mTOR and Raptor did not appreciably change in their localization in fractions 14 and 15 following knockdown of Akt2, suggesting that the loss of IKK subunits from the complex leads to the association with other proteins such that the relative size of the mTOR complex is not altered in a significant manner, or that only a portion of mTOR in these fractions is associated with IKK. Relative to the latter point, mTOR and IKK subunits that are dissociated following knockdown of Akt2 may distribute to other fractions or may be unstable. Further studies are required to understand the molecular components in the Akt-dependent mTOR-IKK complex and in the remaining complexes when Akt activity is suppressed.

The interplay between Akt, mTOR, and IKK is likely to be complex. Akt is known to activate mTOR through phosphorylation and inactivation of TSC2 (see above), thus it is possible that inactivation of TSC2 and loss of its negative control of Rheb leads to an association between IKK and mTOR. Recent work indicates that TSC2 is involved in NF-KB activation (Ghosh et al. 2006), consistent with a potential placement of TSC2 upstream of $\mathrm{mTOR} / \mathrm{IKK}$ and downstream from Akt. Our studies with rapamycin indicate that this drug leads to dissociation of Raptor from the TORC1 complex (as originally shown by

A

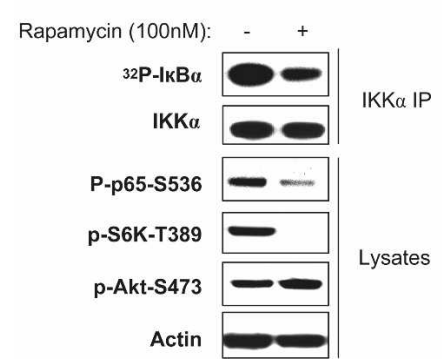

Figure 7. Rapamycin inhibits IKK activity and dissociates Raptor from the mTOR complex. (A) PC3 cells were treated with rapamycin $(100 \mathrm{nM})$ or DMSO for $2 \mathrm{~h}$. Cell lysates were generated and IKK activity was measured by in vitro IKK kinase assay using GST-IкB $\alpha$ as substrate. (B) PC3 cells were treated with rapamycin as in $A$. Cell lysates were immunoprecipitated with anti-mTOR and blotted with mTOR, Raptor, and IKK $\alpha$ antibodies, respectively. 
Sarbassov et al. 2006) but not the dissociation of IKKa (Fig. 7B). This result suggests that Raptor is not required for IKK to associate with TORCl in PTEN-deficient prostate cancer cells. Furthermore, how active TORC1 may induce IKK activity is unclear, although phosphorylation of an IKK subunit by mTOR is a possibility. In this regard, we have been unable to show that mTOR phosphorylates IKK in vitro, although knockdown of mTOR or Raptor block phosphorylation of IKK subunits in their activation loops (see Fig. 6A). Additionally, the observations that knockdown of Raptor or loss of the association between Raptor and mTOR following rapamycin treatment leads to an inhibition of NF-кB activation is consistent with the role of Raptor as a key regulator of TORCl activity, including the NF- $\mathrm{kB}$ activation response.

Rapamycin is a molecule that blocks mTOR activity through a mechanism involving interaction with FKBP12 and subsequent interaction with TORC1 to inhibit mTOR kinase activity (see Sawyers 2003). Rapamycin and its analogs are used to prevent transplant rejection and to suppress restenosis after angioplasty; additionally, its effects on cancer cells in vitro are consistent with a potential as an anti-cancer drug (Sawyers 2003; Guertin and Sabatini 2005; Sarbassov et al. 2006). However, it is clear that only a subset of cancer patients respond to rapamycin (Sawyers 2003). Interestingly, tumors that are deficient in the tumor suppressors PTEN or VHL appear to exhibit sensitivity to rapamycin (Neshat et al. 2001; Podsypanina et al. 2001; Thomas et al. 2006). Our results indicate that NF- $\mathrm{kB}$ activity is suppressed by rapamycin in PTEN-deficient prostate cancer cell lines, raising the potential that the inhibitory effects of rapamycin on NF-кB in PTEN-deficient cells contributes to the therapeutic benefit of this drug in this particular cancer setting.

Akt serves as an essential signaling node downstream from several upstream regulators, including cytokines and growth factors (Manning and Cantley 2007). Via its kinase activity, Akt controls cell survival, proliferation, and growth. Within this group of properties, suppression of apoptosis is a key function of Akt, which is likely to play an important role in the pro-oncogenic functions of Akt. In this respect, Akt phosphorylates and inhibits the BH3-only, proapoptotic protein BAD (see Manning and Cantley 2007). Also, Akt phosphorylates FOXO transcription factors to induce their nuclear export, suppressing their proapoptotic function (Tran et al. 2003). Given the key anti-apoptotic functions ascribed to NF- $\mathrm{kB}$ (see Basseres and Baldwin 2006), it is likely that NF- $\mathrm{BB}$ activation downstream from Akt functions to promote cell survival. Previous evidence for this was provided by Madrid et al. (2001). Our data indicate that Akt, at least in the setting of loss of PTEN function, promotes IKKdependent activation of NF-kB via mTOR and Raptor, which controls the expression of certain key anti-apoptotic genes (see Fig. 4). In this pathway, TORC1 would promote cell survival through a mechanism that is independent of the traditional translational-dependent pathways associated with mTOR activity. Thus, our results provide insight into new regulatory functions of Akt and mTOR.

\section{Materials and methods}

\section{Cell culture and reagents}

HeLa and the prostate cancer cell lines PC3 and LNCaP were from American Type Culture Collection. All cells were maintained in Dulbecco's modified Eagle's medium (DMEM) supplemented with $10 \%$ fetal bovine serum (FBS), 2 mM glutamine, and $100 \mathrm{U} / \mathrm{mL}$ penicillin and streptomycin (Gibco). The reagents were obtained from the following sources: Protease and phosphatase inhibitor cocktails were from Roche; CHAPS was from Pierce; rapamycin was from Calbiochem; LY294002 was from Cell Signaling; and protein A and protein G agarose beads were from Invitrogen Life Technologies. The radiochemicals used were obtained from New England Nuclear. Recombinant GST-p65/RelA C-terminal fragment was provided by Dr. Marty Mayo (University of Virginia).

\section{Antibodies}

Antibodies were obtained from the following sources: Antibodies against IKK- $\alpha$, IKK- $\beta$, mTOR, Akt 1 , and Akt 2 were obtained from Upstate Biotechnology. Anti-Raptor and anti-Rictor antibodies were obtained from Bethyl Laboratories. Anti-actin was obtained from Calbiochem. The anti-myc (9E-10) and control rabbit IgG, as well as HRP-labeled anti-mouse and anti-rabbit secondary antibodies were from Santa Cruz Biotechnology. All other antibodies were from Cell Signaling.

\section{Transfections}

Transfections were performed using Polyfect Transfection Reagent (Qiagen) or Lipofectamine and Plus (Invitrogen) following the manufacturer's instructions. Briefly, $3-4 \mathrm{~h}$ after transfection, cells were recovered in full serum for $36 \mathrm{~h}$ or in full serum for $24 \mathrm{~h}$ and then serum-starved for $16-24 \mathrm{~h}$ as indicated.

\section{RNAi}

siRNA SMARTpool IKK $\alpha$ (catalog \#M-003473), IKK $\beta$ (catalog \#M-003503), Akt1 (catalog \#M-003000), Akt2 (catalog \#M-003001), and mTOR (catalog \#M-003008) were from Dharmacon. Each of these represents four pooled SMART-selected siRNA duplexes that target the indicated mRNA. siRNA to Raptor was from Dharmacon following the article (Kim et al. 2002). PC3 or HeLa cell lines cells were transfected with indicated SMARTpool siRNA or nonspecific control pool using DharmaFECT 1 reagent (Dharmacon) according to the manufacturer's instructions. Briefly, $20 \mathrm{nM}$ final concentration of siRNA was used to transfect cells at $60 \%-70 \%$ confluency. Twenty-four hours after transfection, cells were recovered in full serum or were serum-starved $16 \mathrm{~h}$ before harvest. Cells were harvested $48-72 \mathrm{~h}$ after siRNA transfection.

\section{Size exclusion chromatography}

Lysates were prepared from PC3 cells as described above. A Superose 6 10/300 GL column (GE Healthcare) was equilibrated in lysis buffer containing $50 \mathrm{mM}$ Tris $\mathrm{HCl}(\mathrm{pH} 7.5), 120 \mathrm{mM}$ $\mathrm{NaCl}, 1 \mathrm{mM} \mathrm{NaVO}_{3}, 10 \mathrm{mM} \mathrm{NaF}, 1 \mathrm{mM} \mathrm{DTT}, 1 \mathrm{mM}$ PMSF, 10 $\mu \mathrm{g} \cdot \mathrm{mL}^{-1}$ Aprotinin, and $10 \mu \mathrm{g} \cdot \mathrm{mL}^{-1}$ Leupeptin using a BioRad Duoflow liquid chromatography system. Lysate containing $4 \mathrm{mg}$ of total protein was applied to the column and separated, 
running lysis buffer at $0.4 \mathrm{~mL} / \mathrm{min}$. The volume of elution for each molecular weight was determined using size exclusion chromatography standards (Bio-Rad). Fractions were subjected to SDS-PAGE and immunoblot analysis with antibodies directed toward the indicated proteins.

\section{Cell lysis, immunoblotting, and coimmunoprecipitations}

Cells were lysed and immunobotted as described (Kim et al. 2002) with minor modifications. Briefly, cells grown on 100$\mathrm{mm}$ dishes were rinsed twice with cold PBS and then lysed on ice for $20 \mathrm{~min}$ in $1 \mathrm{~mL}$ of lysis buffer $(40 \mathrm{mM}$ Hepes at $\mathrm{pH} 7.5$, $120 \mathrm{mM} \mathrm{NaCl}, 1 \mathrm{mM}$ EDTA, $10 \mathrm{mM}$ pyrophosphate, $10 \mathrm{mM}$ glycerophosphate, $50 \mathrm{mM} \mathrm{NaF}, 0.5 \mathrm{mM}$ orthovanadate, EDTAfree protease inhibitors [Roche]) containing $1 \%$ Triton X-100. After centrifugation at $13,000 \mathrm{~g}$ for $10 \mathrm{~min}$, samples containing 20-50 $\mu \mathrm{g}$ of protein were resolved by SDS-PAGE, and proteins were transferred to Pure Nitrocellulose Membrane (Bio-Rad), blocked in $5 \%$ nonfat milk, and blotted with the indicated antibodies.

For immunoprecipitation experiments, the lysis buffer contained $0.3 \%$ CHAPS instead of $1 \%$ Triton. Four micrograms of the indicated antibodies were added to the cleared cellular lysates and incubated with rotation for $6-16 \mathrm{~h}$. Then, $25 \mu \mathrm{L}$ of protein G-agarose were added and the incubation continued for $1 \mathrm{~h}$. Immunoprecipitates captured with protein G-agarose were washed three times with the CHAPS Lysis Buffer and two times by wash buffer A ( $50 \mathrm{mM}$ Hepes at $\mathrm{pH} 7.5,150 \mathrm{mM} \mathrm{NaCl}$ ), and boiled in $4 \times$ SDS sample buffer prior to electrophoresis and immunoblotting.

\section{In vitro IKK Assay}

PC3 cells were grown in 100-mm dishes for $48 \mathrm{~h}$ in DMEM containing $10 \%$ FBS and lysed in $1 \mathrm{~mL}$ of lysis buffer with $0.3 \%$ CHAPS. Half of the total cell lysate was incubated with antiIKK $\alpha$, IKK $\beta$, or IKK $\gamma$ antibody for $6-12 \mathrm{~h}$, followed by another hour of incubation with $25 \mu \mathrm{L}$ of protein $\mathrm{G}$ agarose beads. Immunoprecipitates were washed three times with lysis buffer, and once with IKK kinase buffer without ATP $(20$ mM Hepes at $\mathrm{pH} 7.7,2 \mathrm{mM} \mathrm{MgCl} 2,2 \mathrm{mM} \mathrm{MnCl} 2,10 \mathrm{mM} \beta$-glycerophosphate, $10 \mathrm{mM} \mathrm{NaF}, 10 \mathrm{mM}$ p-Nitrophenyl Phosphate [PNPP], $300 \mu \mathrm{M}$ orthovanadate, $1 \mathrm{mM}$ Benzamidine, $2 \mathrm{mM}$ PMSF, $1 \mathrm{mM}$ DTT, $10 \mu \mathrm{g} / \mathrm{mL}$ aprotinin, $1 \mu \mathrm{g} / \mathrm{mL}$ Leupeptin, $1 \mu \mathrm{g} / \mathrm{mL}$ pepstatin, 1 mM DTT). Kinase assay toward recombinant GST-ІкB $\alpha$ (amino acids 1-54) or GST-p65/RelA C-terminal fragment using washed immunoprecipitates was performed for $45 \mathrm{~min}$ at $30^{\circ} \mathrm{C}$ in $30 \mu \mathrm{L}$ of IKK kinase buffer with $10 \mu \mathrm{M}$ ATP and $\left[\gamma^{-32} \mathrm{P}\right] \mathrm{ATP}$ $(0.5 \mu \mathrm{Ci}$ for per kinase reaction). To stop the reaction, $8 \mu \mathrm{L}$ of $4 \times$ SDS sample buffer was added to each reaction, which was boiled for $10 \mathrm{~min}$. The reaction was then separated by $4 \%-12 \%$ SDSPAGE and transferred to PVDF membrane. ${ }^{32} \mathrm{P}$ incorporated into GST-IкB $\alpha$ or GST-p65/RelA C-terminal fragment was assessed by autoradiography.

\section{Reporter assays}

Cells were seeded in six-well plates and were transfected with 700 ng of total DNA using Lipofectamine and Plus (Invitrogen) following the manufacturer's instructions. In all, $200 \mathrm{ng}$ of $3 \times$ $\mathrm{\kappa B}$ luciferase reporter and $50 \mathrm{ng}$ of pRL-SV40 (Renilla reporter control) DNA were cotransfected. Cells were harvested after 24 $\mathrm{h}$ of transfection, and luciferase assays were performed using the Dual Luciferase Assay System (Promega). All transfections were performed in triplicate.
EMSA

EMSAs were performed as described previously (Mayo et al. 1997).

\section{RNA extraction and real-time PCR}

RNA extraction and real-time PCR were performed as described previously (Steinbrecher et al. 2005).

\section{Acknowledgments}

Research support was provided by NIH grants AI35098, CA75080, and CA73756 and a Department of Defense grant (PC073458) to A.S.B.; by a post-doctoral fellowship grant from the Department of Defense Prostate Cancer program to H.C.D; and by an NIH predoctoral training grant (T32 AI007273) to M.J.C. Albert Baldwin is an investigator of the Samuel Waxman Cancer Research Foundation.

\section{References}

Agarwal, A., Das, K., Lerner, N., Sathe, S., Cicek, M., Casey, G., and Sizemore, N. 2005. The Akt/IKK pathway promotes angiogenic/metastatic gene expression in colorectal cancer by activating NF-кB and $\beta$-catenin. Oncogene 24: 1021-1031.

Basseres, D. and Baldwin, A. 2006. NF-кB and IKK pathways in oncogenic initiation and progression. Oncogene 25: 68176830.

Bhaskar, P.T. and Hay, N. 2007. The two TORCs and Akt. Dev. Cell 12: 487-502.

Bonizzi, G. and Karin, M. 2004. The two NF-кB activation pathways and their roles in innate and adaptive immunity. Trends Immunol. 25: 280-288.

Cantley, L.C. and Neel, B.G. 1999. New insights into tumor suppression: PTEN suppresses tumor formation by restraining the PI3K/Akt pathway. Proc. Natl. Acad. Sci. 96: 42404245.

Chen, G., Cao, P., and Goeddel, D.V. 2002. TNF-induced recruitment and activation of the IKK complex require Cdc37 and Hsp90. Mol. Cell 9: 401-410.

Chen, M.-L., Xu, P.-Z., Peng, X., Chen, W.S., Guzman, G., Yang, X., Di Cristofano, A., Pandolfi, P.P., and Hay, N. 2006. The deficiency in Akt1 is sufficient to suppress tumor development in Pten ${ }^{+/-}$mice. Genes \& Dev. 20: 1569-1574.

Dan, H., Adli, M., and Baldwin, A.S. 2007. Regulation of mammalian target of rapamycin activity in PTEN-inactive prostate cancers by IKK $\alpha$. Cancer Res. 67: 6263-6269.

Delhase, M., Li, N., and Karin, M. 2000. Signaling pathways: Kinase regulation in inflammatory response. Nature 406: 367-368.

Downward, J. 1998. Mechanisms and consequences of activation of protein kinase B/Akt. Curr. Opin. Cell Biol. 10: $262-$ 267.

Fingar, D.C. and Blenis, J. 2004. Target of rapamycin (TOR): An integrator of nutrient and growth factor signals and coordinator of cell growth and cell cycle progression. Oncogene 23: 3151-3171.

Ghosh, S., Tergaonkar, V., Rothlin, C., Correa, R., Bottero, V., Bist, P., Verma, I., and Hunter, T. 2006. Essential role of tuberous sclerosis genes TSC1 and TSC2 in NF-kB activation and survival. Cancer Cell 10: 215-226.

Guertin, D.A. and Sabatini, D.M. 2005. An expanding role for mTOR in cancer. Trends Mol. Med. 8: 353-361.

Hahn-Windgassen, A., Nogueira, V., Chen, C.C., Skeen, J.E., 
Sonenberg, N., and Hay, N. 2005. Akt activates the mammalian target of rapamycin by regulating cellular ATP level and AMPK activity. J. Biol. Chem. 280: 32081-32089.

Hara, K., Maruki, Y., Long, X., Yoshino, K., Oshiro, N., Hidayat, S., Tokunaga, C., Avruch, J., and Yonezawa, K. 2002. Raptor, a binding partner of target of rapamycin (TOR), mediates TOR action. Cell 110: 177-189.

Hay, N. 2005. The Akt-mTOR tango and its relevance to cancer. Cancer Cell 8: 179-183.

Hay, N. and Sonenberg, N. 2004. Upstream and downstream of mTOR. Genes \& Dev. 18: 1926-1945.

Hayden, M. and Ghosh, S. 2004. Signaling to NF-кB. Genes \& Dev. 18: 2195-2224.

Inoki, K., Li, Y., Zhu, T., Wu, J., and Guan, K.L. 2003. TSC2 is phosphorylated and inhibited by Akt and suppresses mTOR signaling. Nat. Cell Biol. 4: 648-657.

Israel, A. 2000. The IKK complex: An integrator of all signals that activate NF-кB? Trends Cell Biol. 10: 129-133.

Karin, M. 2006. NF- $\mathrm{kB}$ in cancer development and progression. Nature 441: 431-436.

Kim, D.H., Sarbassov, D., Ali, S., King, J., Latek, R., ErdjumentBromage, H., Tempst, P., and Sabatini, D.M. 2002. mTOR interacts with raptor to form a nutrient-sensitive complex that signals to the cell growth machinery. Cell 110: 163-175.

Kim, D.H., Sarbassov, D., Ali, S.M., Latek, R., Guntur, K., Erdjument-Bromage, H., Tempst, P., and Sabatini, D.M. 2003. $\mathrm{G} \beta \mathrm{L}$, a positive regulator of the rapamycin-sensitive pathway required for the nutrient-sensitive interaction between raptor and mTOR. Mol. Cell 11: 895-904.

Lee, D., Kuo, H., Chen, C., Hsu, J., Chou, C., Wei, Y., Sun, H., Li, L., Ping, B., Huang, W., et al. 2007. IKK $\beta$ suppression of TSC1 links inflammation and tumor angiogenesis via the mTOR pathway. Cell 130: 440-455.

Madrid, L., Mayo, M., Reuther, J., and Baldwin, A.S. 2001. Akt stimulates the transactivation potential of the RelA/p65 subunit of NF-кB through utilization of IKK and activation of mitogen activated protein kinase p38. J. Biol. Chem. 276: 18934-18940.

Majumder, P.K. and Sellers, W.R. 2005. Akt-regulated pathways in prostate cancer. Oncogene 24: 7465-7474.

Majumder, P., Febbo, P., Bikoff, R., Berger, R., Xue, Q., McMahon, L., Manola, J., Brugarolas, J., McDonnell, T., Golub, T., et al. 2004. MTOR inhibition reverses Akt-dependent prostate intraepithelial neoplasia through regulation of apoptotic and HIF-1-dependent pathways. Nat. Med. 10: 594-601.

Manning, B.D. and Cantley, L.C. 2003. Rheb fills a GAP between TSC and TOR. Trends Biochem. Sci. 28: 573-576.

Manning, B.D. and Cantley, L.C. 2007. Akt/PKB signaling: Navigating downstream. Cell 129: 1261-1274.

Mayo, M., Wang, C.Y., Cogswell, P., Rogers-Graham, K., Lowe, S., Der, C., and Baldwin, A.S. 1997. Requirement of NF-кB activation to suppress p53-independent apoptosis induced by oncogenic Ras. Science 278: 1812-1815.

Neshat, M., Melinghoff, I., Tran, C., Stiles, B., Thomas, G., Petersen, R., Frost, P., Gibbons, J., Wu, H., and Sawyers, C.L. 2001. Enhanced sensitivity to PTEN-deficient tumors to inhibition of FRAP/mTOR. Proc. Natl. Acad. Sci. 98: 1031410319.

O'Reilly, A., Rojo, F., She, Q., Solit, D., Mills, G., Smith, D., Lane, H., Hofmann, F., Hicklin, D., Ludwig, D., et al. 2006. mTOR inhibition induces upstream tyrosine kinase signaling and activates Akt. Cancer Res. 66: 1500-1508.

Ozes, O., Mayo, L.D., Gustin, J.A., Pfeffer, S., Pfeffer, L., and Donner, D. 1999. NF-кB activation by TNF requires the Akt serine-threonine kinase. Nature 401: 82-85.

Plas, D.R. and Thompson, C.B. 2005. Akt-dependent transfor- mation: There is more to growth than just survival. Oncogene 24: 7435-7442.

Podsypanina, K., Lee, R., Politis, C., Hennessey, I., Crane, A., Puc, J., Neshat, M., Wang, H., Yang, L., Gibbons, J., et al. 2001. An inhibitor of mTOR reduces neoplasia and normalizes p70/S6 kinase activity in Pten ${ }^{+/-}$mice. Proc. Natl. Acad. Sci. 98: 10320-10325.

Sabatini, D.M. 2006. mTOR and cancer: Insights into a complex relationship. Nat. Rev. Cancer 6: 729-734.

Sarbassov, D., Guertin, D., Ali, S.M., and Sabatini, D.M. 2005. Phosphorylation and regulation of Akt/PKB by the RictormTOR complex. Science 307: 1098-1101.

Sarbassov, D., Ali, S., Sengupta, S., Sheen, J., Hsu, P., Bagley, A., Markhard, A., and Sabatini, D.M. 2006. Prolonged rapamycin treatment inhibits mTORC2 assembly and Akt/PKB Mol. Cell 22: 159-168.

Sawyers, C.L. 2003. Will mTOR inhibitors make it as cancer drugs? Cancer Cell 4: 343-348.

Shah, O.J. and Hunter, T. 2006. Turnover of the active fraction of IRS1 involves raptor-mTOR and S6K1-dependent serine phosphorylation in cell culture models of tuberous sclerosis. Mol. Cell. Biol. 26: 6425-6434.

Shaw, R.J. and Cantley, L.C. 2006. Ras, PI(3)K, and mTOR signaling controls tumor cell growth. Nature 441: 424-430.

Sizemore, N., Lerner, N., Dombrowski, N., Sakurai, H., and Stark, G. 2002. Distinct roles of IKK $\alpha$ and IKK $\beta$ in liberating NF- $\kappa \mathrm{B}$ from IкB and in phosphorylating the p65 subunit of NF-кB. J. Biol. Chem. 277: 3863-3869.

Skeen, J., Bhaskar, P., Chen, C.-C., Chen, W.S., Peng, X.-D., Nogueira, V., Hahn-Windgassen, A., Kiyokawa, H., and Hay, N. 2006. Akt deficiency impairs normal cell proliferation and suppresses oncogenesis in a p53-dependent and mTORC1-dependent manner. Cancer Cell 10: 269-280.

Steinbrecher, K., Wilson, W., Cogswell, P., and Baldwin, A.S. 2005. GSK3 $\beta$ functions to specify gene specific, NF-kB-dependent transcription. Mol. Cell. Biol. 25: 8444-8455.

Thomas, G., Tran, C., Mellinghoff, I., Welsbie, D., Chan, E., Fueger, B., Czemin, J., and Sawyers, C.L. 2006. Hypoxia-inducible factor determines sensitivity to inhibitors of mTOR in kidney cancer. Nat. Med. 12: 122-127.

Tran, H., Brunet, A., Griffith, E., and Greenberg, M.E. 2003. The many forks in FOXO's road. Sci. STKE 2003: RE5. doi: 10.1126/stke.2003.172.re5.

Vivanco, I. and Sawyers, C.L. 2002. The phosphatidylinositol 3-kinase pathway and human cancer. Nat. Rev. Cancer 2: 489-501.

Yang, Q., Inoki, K., Ikenoue, T., and Guan, K.L. 2006. Identification of Sin 1 as an essential TORC2 component required for complex formation and kinase activity. Genes \& Dev. 20: 2820-2832. 


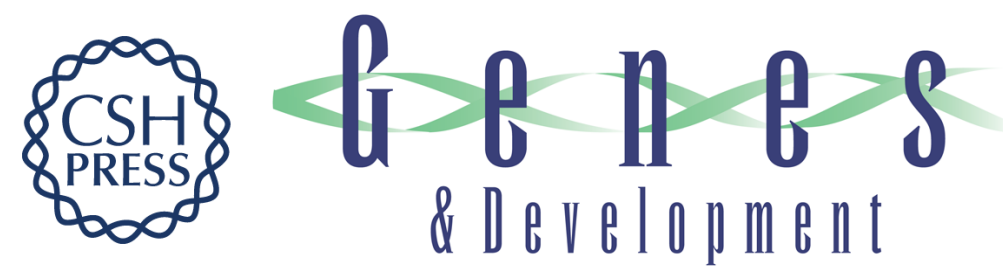

\section{Akt-dependent regulation of NF- $\mathrm{kB}$ is controlled by $\mathrm{mTOR}$ and Raptor in association with IKK}

Han C. Dan, Matthew J. Cooper, Patricia C. Cogswell, et al.

Genes Dev. 2008, 22:

Access the most recent version at doi:10.1101/gad.1662308

Supplemental http://genesdev.cshlp.org/content/suppl/2008/05/21/22.11.1490.DC1
Material

References This article cites 48 articles, 16 of which can be accessed free at: http://genesdev.cshlp.org/content/22/11/1490.full.html\#ref-list-1

License

Email Alerting

Receive free email alerts when new articles cite this article - sign up in the box at the top Service right corner of the article or click here.

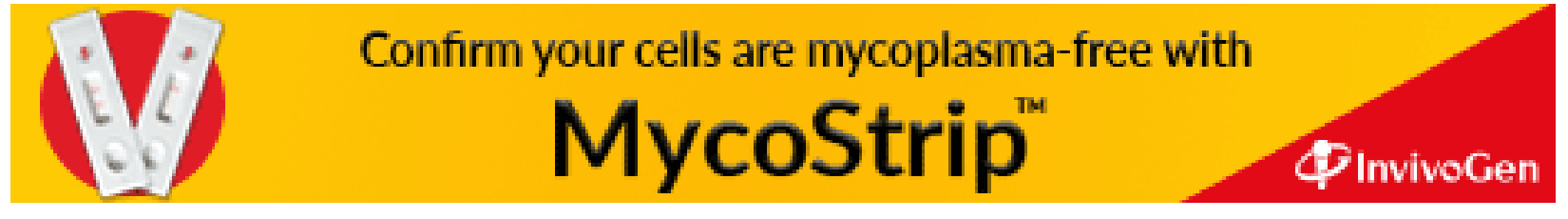

